\title{
Methodological Background of Post-Soviet Regionalism: The Case of Ukraine
}

\author{
Viktor Chuzhykov \\ Oleksandr Fedirko \\ Andrii Chuzhykov \\ Kyiv National Economic University \\ named after Vadym Hetman \\ Prospekt Peremogy Avenue, Building 54/1, \\ Kyiv 03680, Ukraine \\ E-mail: alexfedirko@yahoo.com \\ E-mail: chuzhikov.viktor@mail.ru \\ E-mail: neoman86@mail.ru
}

Abstract: The transformational 1990s significantly differentiated the regional model of Ukraine, which eventually began to resemble a system of uncontrolled chronic economic decline, as the existing planning and regulatory methods had become redundant, the market-based approaches being not actualized. The methodological vacuum in which Ukraine found itself did not allow regions to solve the existing problems by means of European economic convergence instruments. Despite the fact that more and more theories and concepts appeared in the leading developed countries (regional competitiveness, cityregion, beautiful places, creative city, localization, etc.), national science used outdated ideas of planned regulation, inappropriate in market economy. The effect of government policies resembled core measures of the neoliberal model, while maintaining a high degree of administrative centralization.

FDI inflow fundamentally altered the regional landscape. The leading position in accumulating the FDI stock belonged to Kyiv, which also produced the largest per capita GDP. In the last five years a revival of innovation activity took place in the Ukrainian regions. Eventually it obtained an undulating character, moving basically along two axes: Lviv-Kyiv and Kyiv-Kharkiv. However, low FDI level in the worst performing regions could create an erroneous impression about the positive impact of FDI on regional economy. 
A region's development trajectory might also be affected by the mentality of its inhabitants, as well as the media, whose impact can convey either a cohesive or disintegrating character. This was evidenced by the recent events in Ukraine, as well as the "East versus West" confrontation, which resulted in frustration, whereas the lack of tolerance among the population of certain regions provoked the bloodshed. Thus, identification of methodological background of post-Soviet regionalism on the example of Ukraine is an important scientific task, which may explain the essence of regional asymmetries in the post-Soviet states.

Keywords:innovation development, localism, media-holding in Ukraine, Ukrainian region, regionalism

\section{Global and European backgrounds of regional studies}

The aggravation of regional development problems in the past twenty years led to significant shifts in the methodology of regional studies, which had been based on the idea of significant economic distancing of the domestic taxa, not fitting into the framework of the pre-existing model of internal convergence identification. In response to the call of society for new ideas, scientific works proposing to abandon the traditional research schemes appeared one after another. The well-known American expert Michael Storper (1997) proposed a model of territorial development in the context of globalization, which he called 'Regional World'. In his turn, Michael Keating (1998) insisted on the idea of 'new regionalism', which was connected with the territorial restructuring of Western Europe. The idea of optimizing the interrelations between the natural environment and administrative regions, thus harmonizing the relationship between man and nature belongs to Michael McGinnis (1999).

The dawn of the $21^{\text {st }}$ century was marked by a number of sectoral shifts in regional methodology. In particular, a phenomenon of 'regional competitiveness' was grounded, which allowed Gillian Bristow to propose the typology of regional strategies - diversity, dispersion, mutuality, modularity (Bristow, 2010, p. 164). Also a concept of 'city-region' proposed by Andrés Rodríguez-Pose (2008) was established. A significantly increased interest in the non-productive sectors of national economy resulted in the new modern concepts of 'creative class' by Richard Florida (2002) and the 'creative economy' by John Howkins (2007). A little later, Richard Florida, Charlotta Mellander and Kevin Stolarick 
(2011) suggested a somewhat modernized idea of creativization - the 'beautiful places' approach. Paul Krugman's paper (2011), dedicated to the new economic geography and in particular to the fundamental change of regional dynamics assessment methodology, triggered wide debate.

The idea of regional competition is nowadays actively developed. As a result, the concept of the so-called 'territorial product', developed by Roberto Camagni and Roberta Capello (2013), spun off providing a better identification of the regional dynamics in the EU.

In recent years, the role of localization of economic activity has significantly increased, and thus 'localism', according to David Boyle (2010), started to force out the methodology of 'regionalism', and the striking proof thereof is the focus on cluster systems (Baschma \& Fornahl, 2011) and the substantiation of cyclical fluctuations in the cluster models (Martin \& Sunley, 2011).

\section{Regions of Ukraine: from a planned economy to neoliberalism}

Rapid changes in the economy of Ukraine, which took place in the early 1990s, substantially differentiated its regions, thus creating a high asymmetry in the development of administrative units whose parameters in Ukraine fit into the NUTS 2 (Nomenclature of Units for Territorial Statistics), used in the EU. Transformational period of regional differentiation, which lasted for at least fifteen years in Ukraine, had never reached regional stabilization due to the following reasons:

1. The 'transformational crisis' of the 1990s appeared overextended both in time and in space, and was eventually not followed by the systemic reforms. Regional development issues moved to the backburner due to mass impoverishment of the population, and the government gradually began to serve as a fire brigade, guided in its work by the solution of current problems, not the long term ones;

2. Created in the early $21^{\text {st }}$ century, the first official documents (The Concept of Regional Development, the Strategy for Ukraine's Regions Development) turned most likely into a 'declaration of intent', as financial mechanisms and instruments resulted in one per cent of GDP allocation to the needs of regional development. In practice, however, they did not work, as the process of their operation was not thoroughly elaborated, and the declared amount was permanently withdrawn from the budget as an 
optional payment;

3. Planning approaches to the regional development existed for a long time in the minds of Ukrainian people, remaining devoid of financial endowment. However, privatization of large enterprises and their subsequent 'liberation' of social infrastructure significantly worsened the state of local finances, which from then on incurred additional fiscal burden;

4. The Ministry of Regional Development, Construction, and Communal Living of Ukraine, established in December 2010, was granted a number of functions and, at the same time, too little authority and resources for the rapid modernization of regional infrastructure;

5. Internationalization of many regions significantly changed the 'centreperipherals' relations model, unveiling the growing dissatisfaction with the hyper-centralization, which took place over the last four years and was most aggravated in autumn 2014. The government's intention not to sign the EU Association Agreement, as well as high corruption level both in the central and peripheral regions, played the role of a kind of inflammatory element, which served as a catalyst for the second Ukrainian revolution;

6. During the last twenty years in Ukraine, nothing has been done to ensure the consolidation of the society, and scientific advice to the Government on strengthening the intra-regional consolidation between the eastern and western Ukraine, as well as the internal regional economic integration, have not been implemented.

The period of the post-communist transformation in the economic development of Ukraine lasted much longer in comparison with the rest of CEE countries. This led to a series of problems and impediments in its innovation complex, which had been duly considered to be among the leading sophisticated ones within the former USSR republics. In the mid-1990s, the annual GDP decrease amounted to 25 per cent, triggering the growth of regional asymmetries. At the end of the $20^{\text {th }}$ century, gross regional product per capita of Kyiv (the capital of Ukraine) arrived at almost 50 per cent of the EU-15 average GDP of Region (NUTS 2), whereas the remaining Ukrainian regions were identified on the level of 15 to 25 per cent, thereof.

At the beginning of the $21^{\text {st }}$ century, the monocentric development was overcome, in part due to the intensive growth of basic metals exports of the Donetsk and Dnepropetrovsk regions, which experienced some rapprochement with the capital city, however lagging far behind the latter. At the same time, the asymmetries in the per capita gross regional product between the capital city and the depressed regions of Ukraine (e.g., the Chernivtsy and Ternopil regions) have gained the ratio of $3: 1$ in favor of Kyiv. In the middle of the first 
decade of the $21^{\text {st }}$ century, the regional economic heterogeneity was even further aggravated. At the start of 2011, the ratio 'Kyiv vs. Ukraine' was 3:1, and 'Kyiv vs. Chernivtsy region' was as high as 6.4:1. The comparable disproportions in the ratio 'Kyiv vs. Ukraine' sustained with respect to per capita FDI (8.3:1 in $1996 ; 5.1: 1$ in 2006, and 8.16:1 as of 31 December 2012). Thus the capital city of Ukraine produces 18.2 per cent of the national GDP, concentrating almost half of the FDI stock in 2012.

A similar problem of overconcentration is also characteristic of some small CEE countries (Estonia, Hungary, Czech Republic, Slovakia), which experience significant concentration of business activities in their central regions. For Ukraine, however, the situation is not a typical one, as the population of Kyiv accounts for less than 7 per cent of the total population of the country.

The cause for further regress in the innovation development of Ukrainian regions is the unbalanced structure of the FDI. The engineering sector accounted for only 8.3 per cent of the manufacturing FDI stock, whereas basic metals' share of the same indicator amounted to 42 per cent in 2011. This might prepare the ground for a certain technological re-equipment of steel-producing regions, but will conserve their traditional specialization profile for years on end. So, these regions might be treated as the old industrial regions according to the EU classification.

The desire to use the so-called 'manual regulation' unfortunately remains hitherto an issue of current importance for Ukraine. The local population quite often prefers to vote for the political parties which promise to improve the state of social infrastructure, although unclear at the expense of what sources. Common people are acquainted neither with the neoliberal nor with the neo-Keynesian approaches to the regional economic development. That is why they connect their lives with the coming to the power of some scandalous persons. Ukraine was a unique state where the ruling political force has been the Party of Regions, whose activity, however, had never influenced the development of regions.

The other peculiarity, as already mentioned above, is the overcrowding of business activities in the capital of Ukraine. Added to this should be the fact that FDI, acquired once by the other regions, showed a rare tendency to migration and rather quickly found themselves in Kyiv, creating disparities in wages, employment, housing prices and the quality of social services. At the same time, European regional policy had always been of great interest for Ukraine. Its main features are consistency and the availability of important national development mechanisms and instruments, especially in the intellectual sphere.

Some key features of the Ukrainian regional development model are summarized in Table 1. 
Table 1. Main features of the neoliberal model of regional innovation development in Ukraine.

\begin{tabular}{|l|l|}
\hline Key feature & Outcomes \\
\hline $\begin{array}{l}\text { Preservation of the Soviet-style } \\
\text { of thinking within the 'dirigiste' } \\
\text { model of regional development } \\
\text { administration }\end{array}$ & $\begin{array}{l}\text { Lack of funding for the implementation of } \\
\text { the planning model of regulation }\end{array}$ \\
\hline $\begin{array}{l}\text { 'Metropolitan maximum' of } \\
\text { investment and unstable } \\
\text { regional innovation boom } \\
\text { Significant budget appropriations cuts for } \\
\text { the needs of regions' development }\end{array}$ & $\begin{array}{l}\text { Overconcentration of investment in the } \\
\text { capital city (40\% FDI in Ukraine) }\end{array}$ \\
\hline $\begin{array}{l}\text { Quite insignificant volumes of innovations } \\
\text { implemented in regions, whose slight } \\
\text { European mechanisms and } \\
\text { instruments of development } \\
\text { coupled with the insufficient } \\
\text { funding thereof }\end{array}$ & $\begin{array}{l}\text { incease provokes the illusion of an } \\
\text { 'innotion boom' }\end{array}$ \\
\hline
\end{tabular}

Figure 1. Regional FDI inflows as a factor of economic performance, UAH millions.

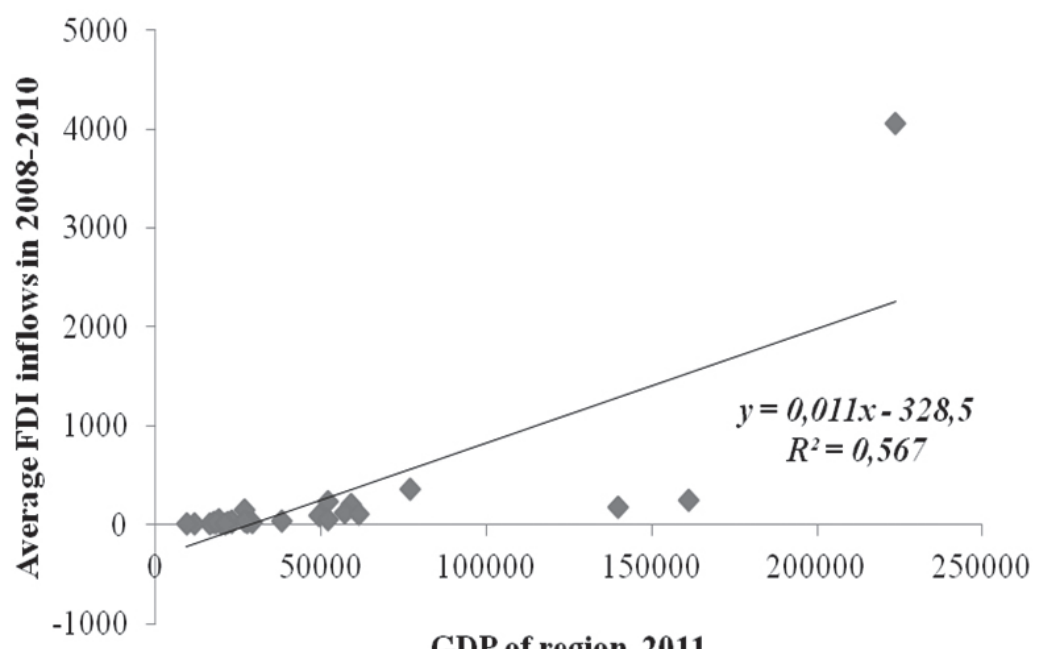

GDP of region, 2011

The increasing foreign direct investment, which took place in Ukraine in the last decade, influenced significantly the regional production structure. As a result, a significant NUTS 2 regions' distancing in terms of FDI came into place with the absolute leadership of the capital of Ukraine, which at the end of 2013 
concentrated almost 50 per cent of the total FDI stock (Fig. 1). However, the role of this indicator as the driver of the region's GDP growth should not be overestimated, because of the deformed sector structure, wherein the most of FDI were absorbed by the financial and banking sectors, as well as by trade and repair of household equipment sectors. Investment in manufacturing and construction did not exceed 7 per cent of the total FDI, and therefore contributed neither to job creation nor to the production of goods and services.

\section{Regional innovation waves: a new economic phenomenon or the old legacy?}

In the graphical analysis presented below we study the regional waves of innovation development in Ukraine. Two spatial approaches were used to create the profile of innovative development: from the east to the west, and from the north to the south of the country.

Figures 2 and 3 uncover the innovation products output-one of the main performance indicators for the regional innovation system. In the period of 2000-2010 these indicators were quite stable, the relevant leaders were Kharkiv (east) and Lviv (west) regions. The launch of new commodities production in the Poltava region led to a significant upsurge of this indicator, which later proved its temporary nature.

Figure 2. Innovation products output (from the West to the East), UAH thousands.

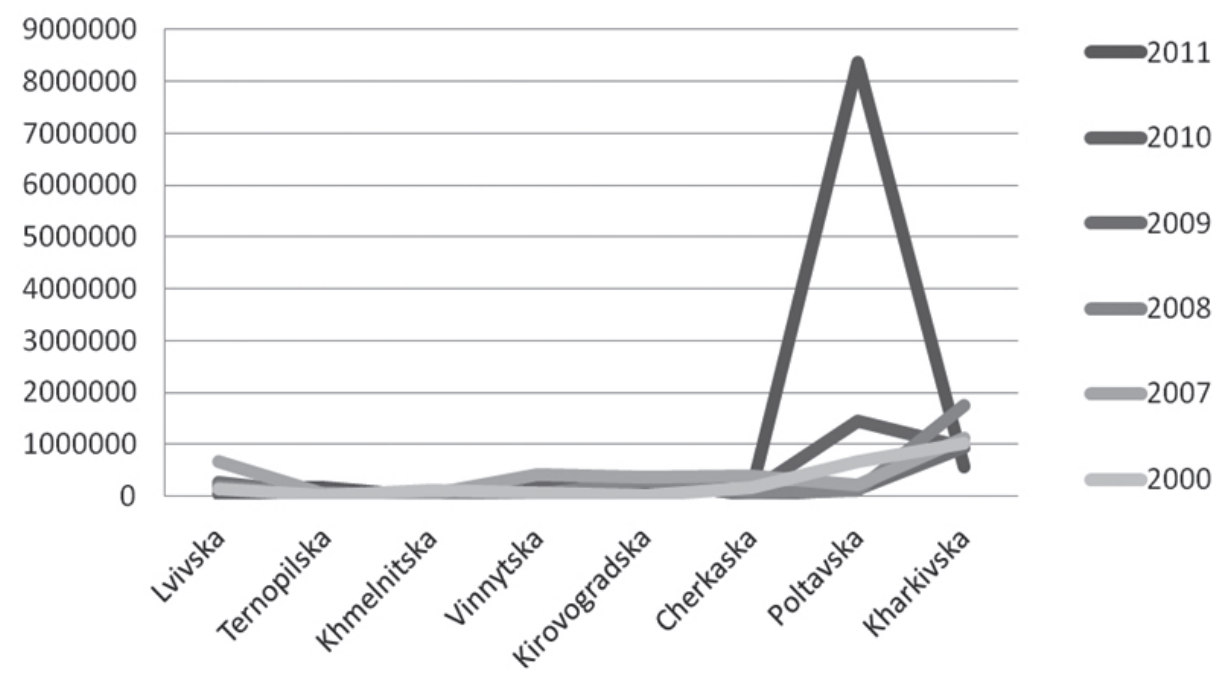


Figure 3 depicts two wave-crests of innovation products output (the city of Kyiv, Dnepropetrovsk and Zaporizhia regions), connected with the significant modernization of the obsolete technological base in the industrial hubs.

Figure 3. Innovation products output (from the North to the South), UAH thousands.

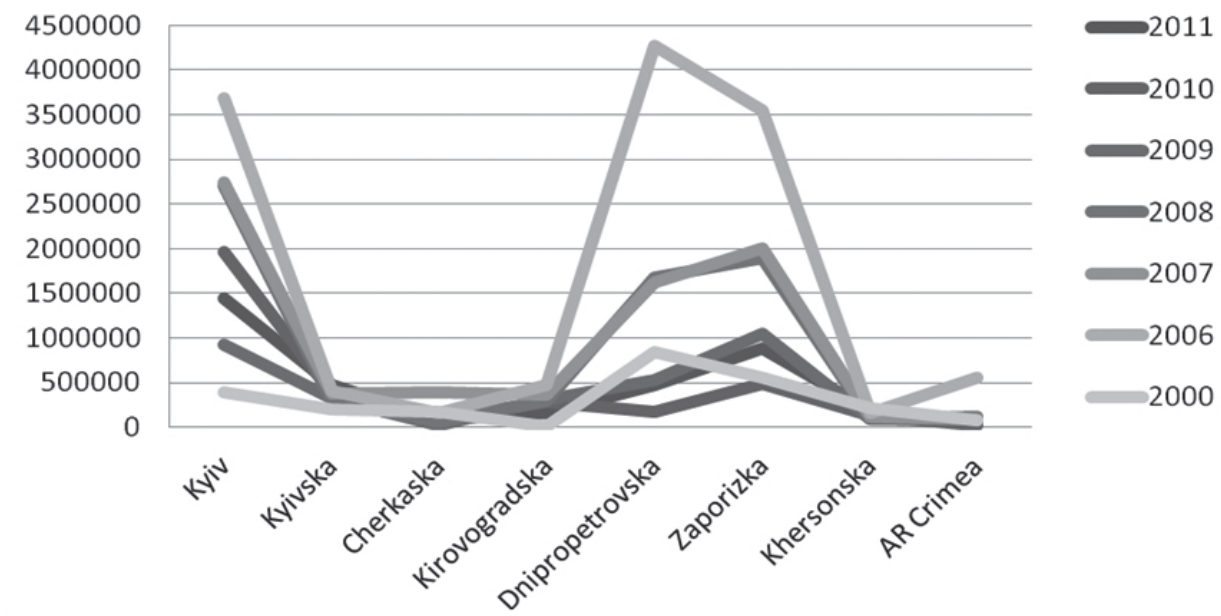

The growing leadership in innovation expenditures (mainly due to the purchase of hardware and equipment) was enjoyed by Khmelnitskyi, Poltava and Kharkiv regions (Figs. $4 \& 5$ ). The 'North-South profile' affirms the earlier trend with the two stable peaks (the city of Kyiv, Dnepropetrovsk and Zaporizhia regions) and an ad hoc asymmetry in the Autonomous Republic of Crimea.

Figure 4. Innovation expenditure (from the West to the East), UAH thousands.

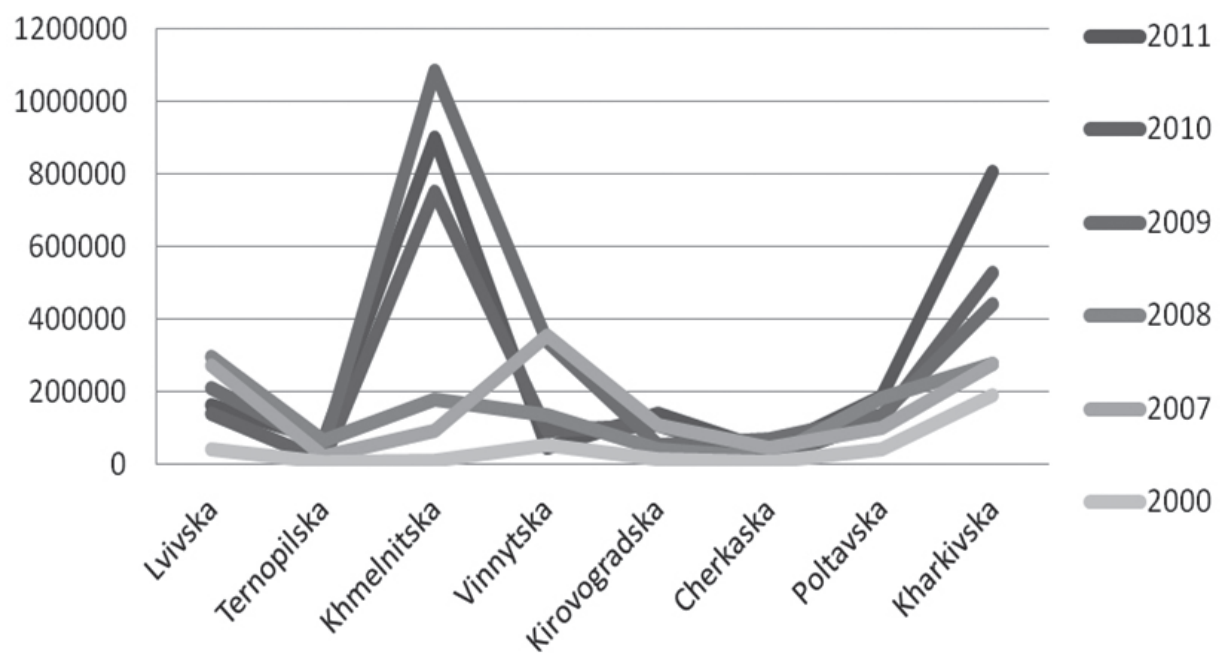


Figure 5. Innovation expenditure (from the North to the South), UAH thousands.

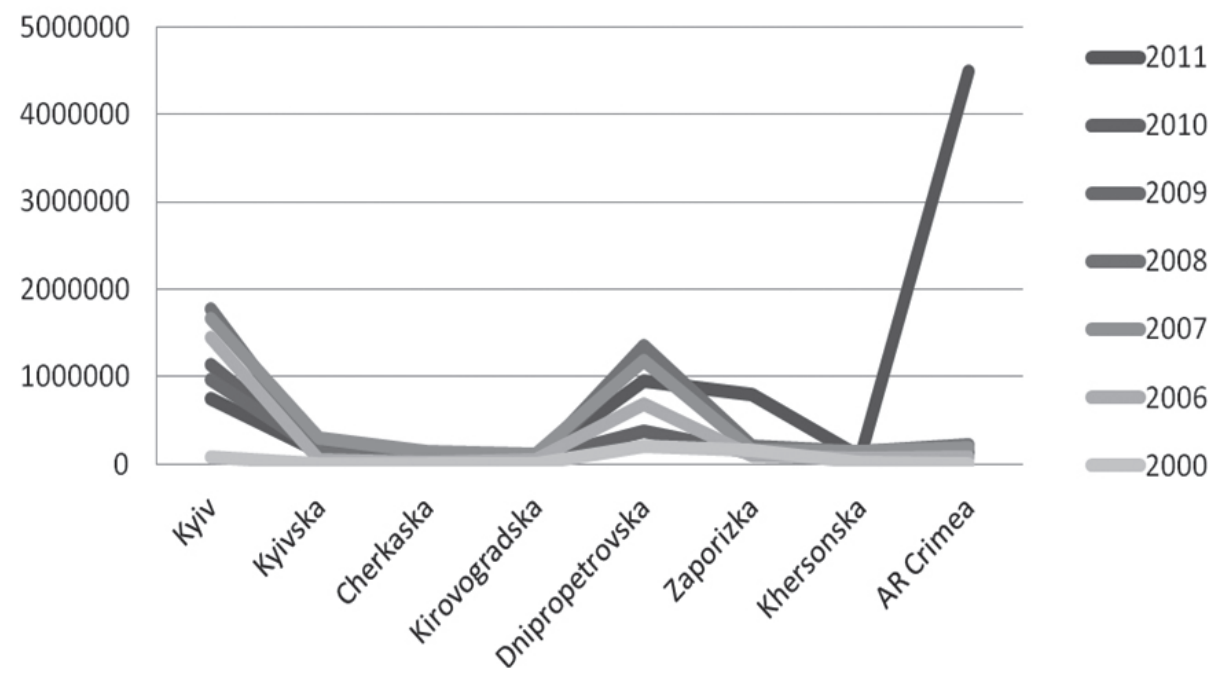

At the same time, judging from Figure 6, intellectual leadership belongs to Kharkiv region with its center in the city of Kharkiv, whose technological intensity is insignificantly inferior to that of the capital of Ukraine. Figure 7, however, proves Kyiv's leadership within the country, as well as regional leadership of the two powerful regional centers.

Figure 6. IPR protection documents granted by the State Intellectual Property Department of Ukraine (from the West to the East), no. of patents.

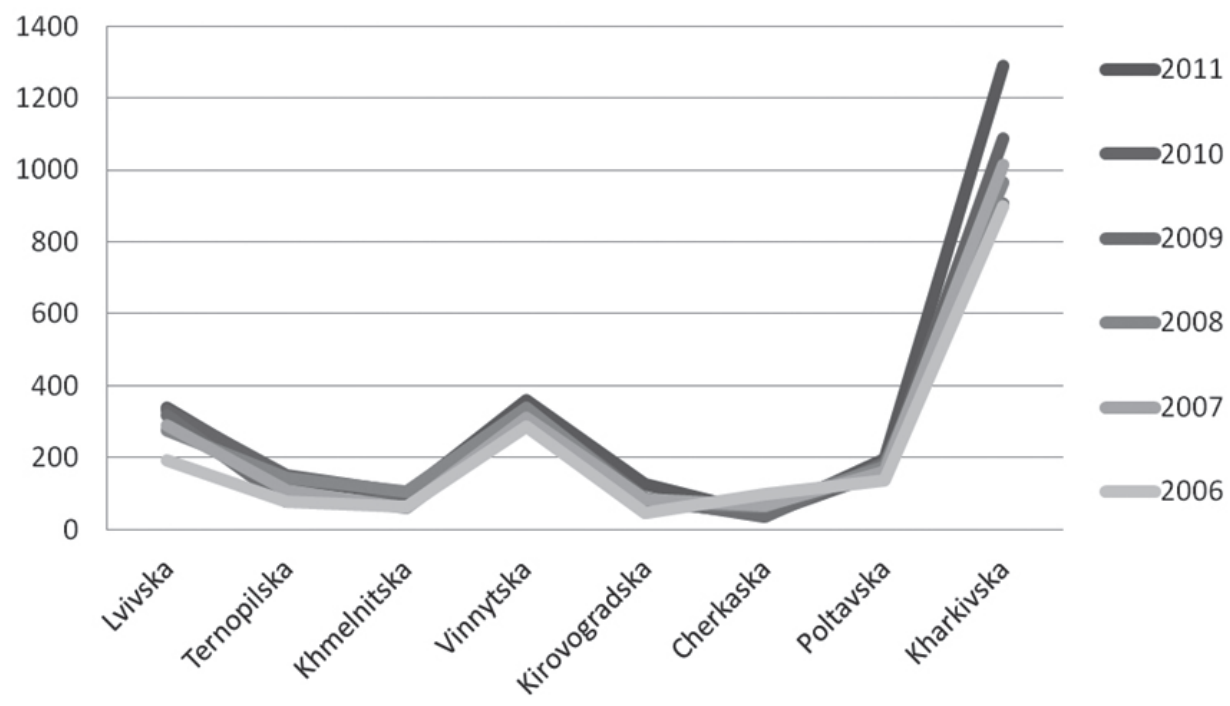


Figure 7. IPR protection documents granted by the State Intellectual Property Department of Ukraine (from the North to the South), no. of patents.

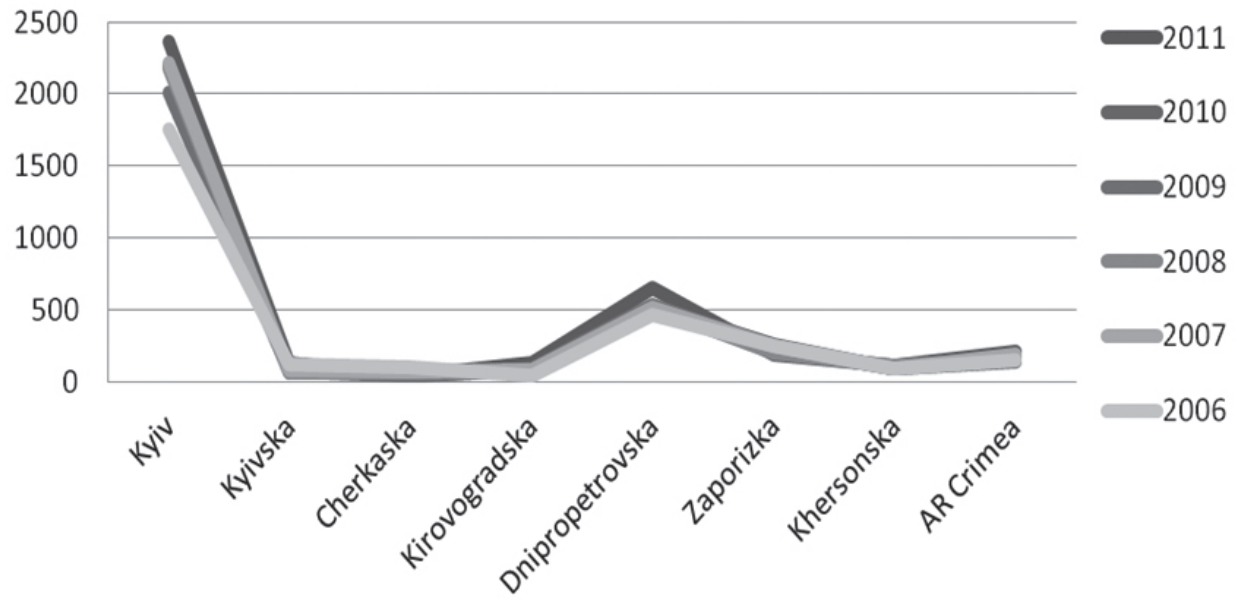

The above analysis allows us to draw a number of important conclusions concerning the innovation model of regional development of Ukraine, as well as to define the factors affecting the regions' positions in Ukraine:

- Nearly absolute lack of regional planning due to poor financing of such projects. The President's proposal on the establishment of the Regional Development Fund of Ukraine is pending acceptance. Thus we may conclude that Ukraine tends to implement a neoliberal rather than neo-Keynesian model of regional development;

- Active migration of the creative staff both to the capital city region and abroad aggravates intellectual disparities, whereas the economic effect of the out-sourcing of a number of companies is reaped beyond the Ukrainian borders;

- Reluctance of both foreign and national businesses to invest in high-tech and innovation spheres (the unofficial second capital area, Kharkiv region, received 8.8 times less FDI per capita in comparison with Kyiv);

- Estimates concerning the growth of military exports remain unjustified (although Ukraine was included in the top ten world weapons exporters at the beginning of the $21^{\text {st }}$ century, it risks of losing these positions due to the lack of technological upgrade of fixed capital. This will affect Kharkiv and Dnepropetrovsk regions most of all). 


\section{Media factor in the emergence of political and economic deformations in the regions of Ukraine}

The influence of media has always been crucial, both in terms of mobilization of population for specific tasks and for its differentiation into separate interest groups. In the 1920s, radio was the kind of media resource, certain telecasts of which could trigger panic among people (Scannel, 2008, pp. 21-23). In the 1960s and 1970s, media began to serve an important ideological function, and a new media resource - television - was added to a large number of newspapers and radio channels (Scannel, 2008, pp. 198-201). A little later, starting from the 1990s, the Internet united all countries in the global information network, requiring new relevant skills and education for those involved in the media business (Mitchell, 2009). Every year, the combination of different modern media resources' influence on population is becoming more and more globalized and absolute. At the same time, the cognitive impact of this process on regional elites, which has acquired a clear localization character, is increased every year. Such an impact, differentiated across the territorial arrangement of a state, can significantly alienate a specific problem, or vice versa, update it and encourage viewers to certain actions within a short period of time. The emergence of a number of broadcasters within a country with the leading regional airs not being owned by a single person as a whole lead to a wide differentiation of the existing channels and programs, providing society with the pluralism. Instead, the country's TV and radio conglomeration pushes it to deep social and economic disparities by broadcasting similar messages and related prime-time structures. Additionally, in many cases, the presence of foreign media companies in the domestic market may be considered hazardous, because they can broadcast not only neutral information (e.g., BBC's wildlife programs) but also selectively and thoroughly processed one. Any combination thereof can have both reinforcing and lowering synergistic effects.

Ukraine's media space has undergone a number of significant transformations over the last twenty years, which have resulted in its significant differentiation. Some basic trends from the beginning of the accelerated growth of the number of media companies became now evident: their share in this market in the 1990s was less than one per cent, but the subsequent consolidation of the domestic media market in 2000-2005 has led to the emergence of some sizeable mediaholding structures. Nowadays in Ukraine there are four such organizations, which are essentially trusts by nature: 'Media Group Ukraine', 'StarLightMedia', '1+1 Media', and 'Inter Media'. Together they control virtually the entire national media space (except for the state and municipal broadcasting segments), as well 
as the newspaper, magazine and advertising business. The names of the five most popular channels are consonant to their media holdings' brands: 'Inter', ' $1+1$ ', 'STB Ukraine', and 'ICTV'.

The events of late 2013 and early 2014, which took place in Ukraine, significantly dissociated the audience preferences, and 'regionalism parade', reinforced by external factors, occasionally divided the now poorly integrated Ukraine into the supporters and opponents of federalism. This situation significantly affects not only the authorities and their language policy, but also human relations in the region.

\section{Conclusions}

The good "starting" position in which Ukraine found itself in the early 1990s, unfortunately, was not effectively exploited because of the inconsistency, discontinuity and asymmetry of the reforms carried out. This is most clearly reflected in the regional system of the country, which quickly became unmanageable, and the reaction of many governments that succeeded one another led to a rigid centralized management.

However, the "free ride" wherein the regions of Ukraine found themselves, coupled with a lack of feasible convergence mechanisms, rather strongly resembled the core of the neoliberal governance model. The basic measures of this model led to the 'West vs. East' conflict, which clearly manifested itself during the events of 2013-2014, and under the influence of domestic and foreign mass media, especially television, contributed significantly to the polarization of Ukrainian society, simultaneously revealing the fact that the delayed reforms, coupled with a disregard of internal regional integration, turned extremely dangerous for the integrity of the country.

The FDI inflows to Ukraine, which should have changed the regional economic landscape and promoted the territorial convergence, have not reached their necessary parametrical qualities so far, because they are mainly focused on selective business areas, such as finance and banking, trade and repair of household equipment. The most attractive among the regions is the city of Kyiv, where about 50 per cent of all the FDI stock in Ukraine is concentrated.

Despite all the complications in the development of Ukrainian regions, there is an evident trend of the innovative performance upsurge in some territorial localities in recent years. This is true for both foreign and domestic investments, which 
reveal not only regional but also some local effects. The role of a 'locomotive' could be taken over by clusters, which provides a clear definition of the nature and mechanisms of cluster policy by the Ukrainian government.

Prof. Viktor Chuzhykov is Doctor of Economic Science and head of the European Integration Department at the Faculty of International Economics and Management, Kyiv National Economic University named after Vadym Hetman. He also manages the master's degree program in European integration. Viktor Chuzhykov is the author of more than 130 scientific papers. Currently professor, he is running three Jean Monnet projects in economic and interdisciplinary studies: a European module "European Integration Advocacy Training" (2011-2014), a European module "European Union Innovation and Investment Development" (2012-2015), and the Jean Monnet Chair "European Regional Development Model" (2012-2015). Viktor Chuzhykov is the president of the public organization European Integration Promotion Foundation. He actively develops international scientific cooperation through a number of international networks, being an active member of Regional Studies Association (UK), acting Jean Monnet Chair, extending scientific partnership and cooperation with colleagues from the University of Warsaw, Krakow University of Economics (Poland), London Metropolitan University, the University of Newcastle (UK), Technical University of Košice (Slovak Republic), and many others.

Oleksandr Fedirko holds a PhD in world economy and international economic relations (since 2005), he is associate professor of European integration and deputy head of the European Integration Department at Kyiv National Economic University. Dr. Fedirko has a 12-year experience in scientific, educational and consulting practices. He is currently a post-doctoral research fellow, working at his Doctor of Economic Sciences degree thesis in the field of European studies.

Andrii Chuzhykov, MSc is a creative producer at Tele Pro production for the national TV channel 'Ukraina'. His previous position was executive producer of STB TV channel. Nowadays Andrii Chuzhykov is attending PhD course in international economics at the Kyiv National University of Economics and has a practice of teaching European integration at the Faculty of International Economics and Management. Andrii Chuzhykov is the author of ten papers. 


\section{References}

Boschma, R. \& Fornahl, D. (2011), 'Cluster Evolution and a Roadmap for Future Research', Regional Studies, vol. 45, no. 10, pp. 1295-1298.

Boyle, D. (2010), Localism: Unraveling the Supplicant State, London: New Economic Foundation.

Bristow, G. (2010), "Resilient regions: re-"place'ing regional competitiveness," Cambridge Journal of Regions, Economy and Society, vol. 3, no. 1, pp. 153-167. http://dx.doi.org/10.1093/cjres/rsp030

Camagni, R. \& Capello, R. (2013), 'Regional Competitiveness and Territorial Capital: A Conceptual Approach and Empirical Evidence from the European Union', Regional Studies, vol. 47, no. 9, pp. 1383-1402. http://dx.doi.org/10.1080/00343 404.2012.681640

Florida, R. (2002), The Rise of the Creative Class, New York: Basic Books.

Florida, R.; Mellander, C. \& Stolarick, K. (2011), 'Beautiful Places: The Role of Perceived Aesthetic Beauty in Community Satisfaction,' Regional Studies, vol. 45, no. 1, pp. 33-48. http://dx.doi.org/10.1080/00343404.2010.486784

Howkins, J. (2007), The Creative Economy: How People Make Money from Ideas, London: Penguin Books.

Keating, M. (1998), The New Regionalism in Western Europe: Territorial Restructuring and Political Change, Cheltenham: Edward Elgar Publishers.

Krugman, P. (2011), 'The New Economic Geography, Now Middle-aged,' Regional Studies, vol. 45, no. 1, pp. 1-7. http://dx.doi.org/10.1080/00343404.2011.537127

Martin, R. \& Sunley, P. (2011), 'Conceptualizing Cluster Evolution: Beyond the Life Cycle Model?’ Regional Studies, vol. 45, no. 10, pp. 1299-1318.

Mitchell, L. (2009), Production Management for Television, London \& New York: Routledge.

Rodríguez-Pose, A. (2008), 'The rise of the "City-Region" concept and its development policy implications,' European Planning Studies, vol. 16, no. 8, pp. 1025-1046. http://dx.doi.org/10.1080/09654310802315567

Scannell, P. (2008), Media and Communication, London: Sage Publications.

Storper, M. (1997), The Regional World: Territorial Development in a Global Economy, New York \& London: The Guilford Press. 